\title{
RISK ANALYSIS OF FOUNDATION WORK IN CONSTRUCTION PROJECTS OF 6 (SIX) TOLL ROADS IN THE CITY TO IMPROVE TIME PERFORMANCE
}

\author{
CHANDRA FERTILIA NOVIKA \\ Faculty of Engineering \\ University Mercu Buana Jakarta Indonesia \\ novikacandraf@yahoo.com \\ IKA ANGGRAENI ELFERA \\ Faculty of Engineering \\ University Mercu Buana Jakarta Indonesia \\ elfera.anggraeni@gmail.com
}

\begin{abstract}
The Jakarta inner ring toll road is a toll road that surrounds the inner city of Jakarta. Due to the dense number of vehicles and traffic congestion on the existing inner-city toll roads, the DKI Jakarta Provincial Government plans to increase the number of inner-city toll roads to 6 sections. The project development begins with Section 1A, namely from Kelapa Gading - Pulo Gebang. At present development is still at the stage of foundation work where progress in October 2019 only reached $80.97 \%$ of the target of $100 \%$. The work has been delayed and has been extended 2 times. From these problems, this study was conducted to analyze the high risks that affect the time performance of foundation work and corrective and preventive actions. In this study data collection was carried out by distributing 4-step questionnaires, namely expert validation, pilot survey, respondents and final expert validation. Risk ranking is analyzed using MS. Excel is based on a probability and impact matrix table that aims to determine variables that have a high level of risk. From the results of data analysis, there are 4 variables that fall into the high risk category, namely the problem of land acquisition, work location is not ready, work drawings are not ready, and the core staff of the project are less competent. The results of expert recommendations for the four variables can be stated in preventive and corrective actions.
\end{abstract}

Keywords : Risk, time performance, toll road, foundation

\section{INTRODUCTION}

Roads are a means for the mobility of goods and people. In big cities such as Jakarta, many highways have already exceeded the planned capacity, causing congestion to occur. The increased production of motor vehicles and the ease of the buying process are the main factors increasing the number of motorized vehicles on the road. From these problems, the Government built a toll road that aims to reduce the burden of traffic and congestion that occurs on public roads and reduce air pollution due to slow or stagnant motorized vehicles. And the Jakarta Inner Ring Road (JIRR) was built, which is a toll road that circles the inner city of Jakarta. This toll road is divided into 3 parts namely Cawang - Pluit Toll Road (Jakarta Intra Urban Tollroad), Port Toll Road (Pluit - Tanjung Priok toll road) and Ir. Wiyoto Wiyono (Cawang - Tanjung Priok section). Due to the high number of vehicles and traffic congestion on the toll road, the DKI Jakarta Provincial Government plans to increase the inner-city toll road to 6 (Six) sections, namely Kampung Melayu - Kemayoran (9.6 km), Semanan - Sunter through Rawa Buaya Duri Pulo ( $22.8 \mathrm{~km}$ ), Kampung Melayu - Duri Pulo via Tomang (11.4 km), Sunter - Pulo Gebang via Kelapa Gading (10.8 km), Ulujami - Tanah Abang (8.3 km), and Pasar Minggu - Casablanca $(9.5 \mathrm{~km})$. The construction of 6 (six) toll roads is mostly elevated, along the river and railroad lines (Project Document, 2017). In the first section, the development is divided into 3 sections, namely Section A from Kelapa Gading to Pulo Gebang, Section B from Semanan to Grogol and Section C from Grogol to Kelapa Gading. The project development starts from section A, from Kelapa Gading to Pulo Gebang. 
This project uses a type of bored pile foundation with a diameter of $1200 \mathrm{~mm}$ where the volume of drilling reaches $96,596.22 \mathrm{~m}$ with a planned time to carry out the foundation work from September 1, 2017 to April 1, 2018. But the reality on the ground with the schedule is the work the foundation has not been completed and has completed an extension of the time for completion 2 (two) times, namely until 31 October 2019 where the work must reach $100 \%$ progress. Until the end of October 2019 the work progress only reached $80.79 \%$ from $100 \%$. As a result of the delay in completion, the foundation contractor lost \pm 5 billion. This is a serious concern because other projects did not occur. Therefore, researchers want to identify and analyze high risks that affect the time performance of foundation work along with preventive and remedial actions.

Project risk management aims to identify and manage risks that are not handled by other project management processes. When not managed, this risk has the potential to cause the project to deviate from the plan and fail to achieve the stated project goals. As a result, the effectiveness of project risk management is directly related to project success (PMBOK Guide Sixth Edition, 2017).

Risk level analysis is based on the Risk Level Index equation, where the magnitudes of the Risk Level Index are a picture of the level of risk that occurs. In accordance with (PMBOK Guide Sixth Edition, 2017), evaluation of risks in a project depends on:

1. The probability of occurrence of risk and frequency of occurrence.

2. Impact of these risks.

3. Risk level index with the following equation:

$$
\begin{aligned}
& R=I \times P \ldots \ldots \ldots \ldots \ldots \ldots \ldots \\
& \text { with: } \\
& R=\text { Risk Level Index } \\
& I=\text { Frequency/Probability } \\
& P=\text { Impact }
\end{aligned}
$$

\section{RESEARCH METHODOLOGY}

The thinking framework used in this study is a scientific approach that shows the relationship between independent variables and dependent variables in the process of analysis. The thinking framework can be outlined in the following scheme:

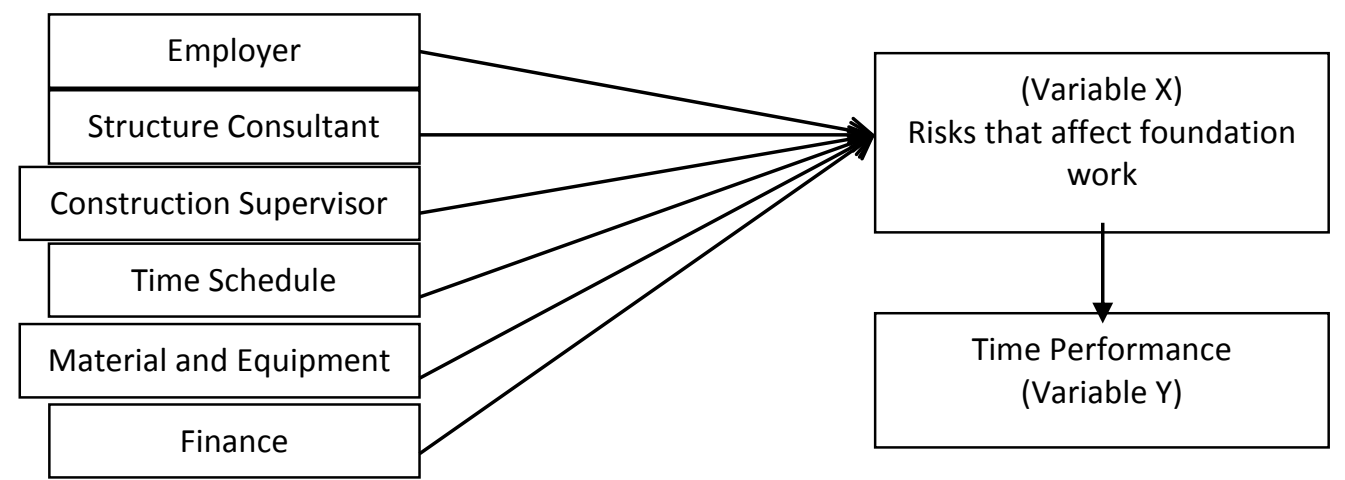

Figure 1. Scheme of Thinking Framework (Source: Processed by the author, 2019)

As for the research flow chart, see figure at the below: 


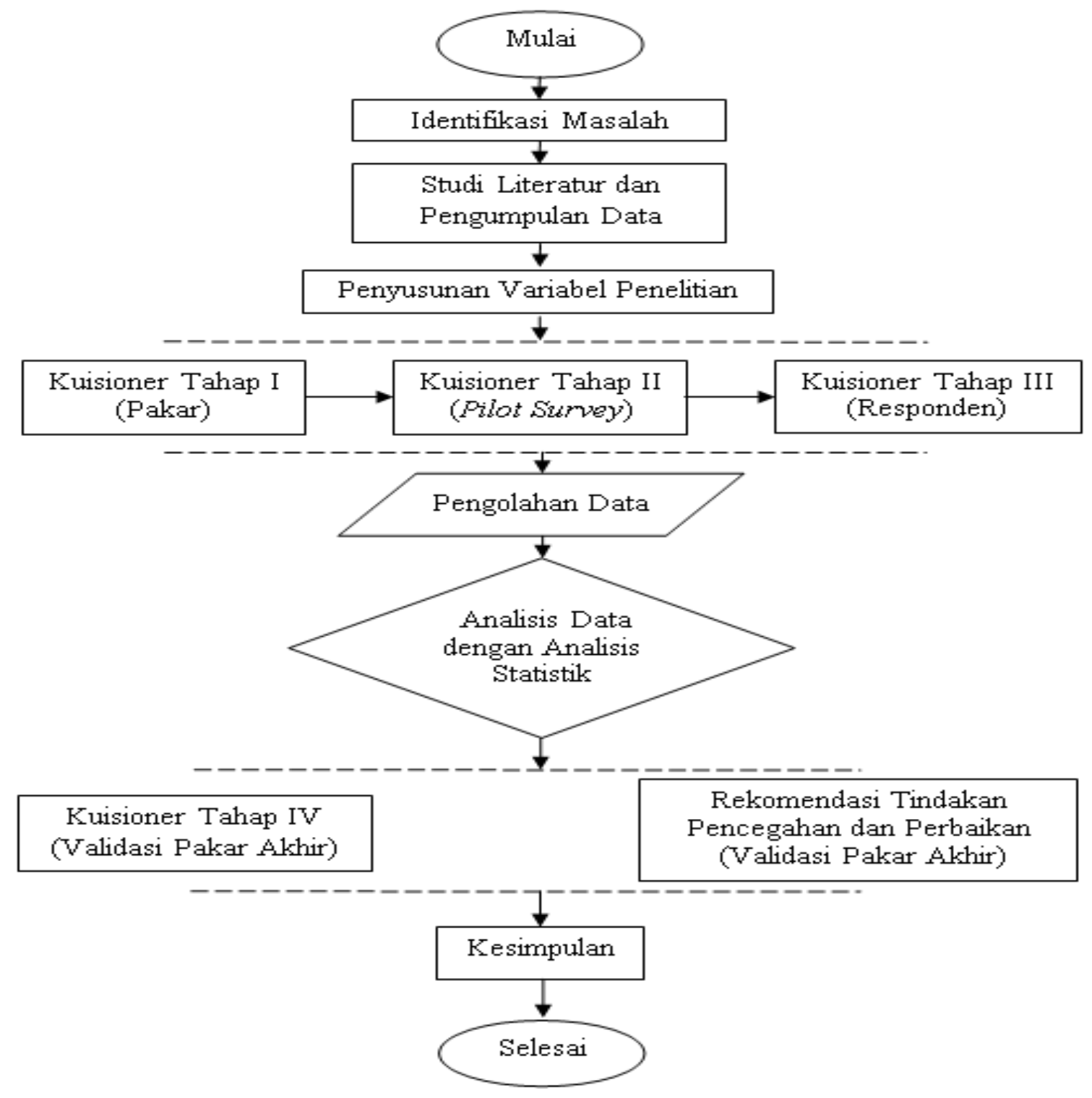

Figure 2. Research Flow Chart

(Source: Ilustration by the author, 2019)

In this study the authors began to conduct research by determining the object of the project that will be used as a research project, namely the Development of 6 Toll Roads in the City Section 1A Kelapa Gading - Pulo Gebang.

After determining the object of research, the authors identify the problems experienced by the project. Then the authors make the formulation of the problem that will be a reference in research activities.

The next stage is the writer conducts a literature study by studying various journals related to the risks that occur in the project. From the journal the writer obtained some data, namely variables that have been studied, procedures that have been applied and results in research. After reviewing various journals, the author compiles variables that will be the basis for making the questionnaire. The results of the distribution of questionnaires will be the primary data in this study. In addition to distributing questionnaires, primary data were obtained by interviewing those involved in the implementation of the project (contractor), especially those 
who were competent and knew the project conditions. In this study there are secondary data that will be used, namely time schedule for the implementation of foundation work.

Arrange the first stage questionnaire which aims to ask the opinions of experts (experts) on the questionnaire that has been made by the author. This step can be said as a validation of the questionnaire whether the expert agrees or not that the variables that exist are risks that affect time performance. In addition, ask experts to add or subtract existing variables.

The distribution of questionnaire phase II (pilot survey) where in this activity the writer spreads the questionnaire to several prospective respondents.

Distribution of stage III questionnaire where the questionnaire is the main questionnaire and distributed to several respondents. The respondents are selected people who are competent and know the conditions that occur in the project. To identify risk variables, a qualitative method of data analysis was carried out, namely interviewing experts and continued with quantitative data analysis for the results of the questionnaire from respondents. The data that has been collected is processed using the SPSS (Statistical for Social Science) program for validation and reliability testing. After that the results of the questionnaire were analyzed with the Risk Index method to determine the level of risk that occurred.

The distribution of the stage IV questionnaire was carried out to obtain recommendations from experts on the results of the analysis of research data. These opinions include preventive measures and corrective actions. Researchers provide conclusions in the form of answers to the identification of problems related to risk that affect the time performance of foundation work and the most dominant risk.

From the results of the literature study, the following research variables were obtained:

Table 1. Research Variables

\begin{tabular}{|c|c|c|}
\hline Variables & Risks that affect time performance & Sources \\
\hline $\mathrm{X} 1$ & $\begin{array}{l}\text { Occurrence of Natural Disasters (Force } \\
\text { Majeure) }\end{array}$ & Evan, 2017 \\
\hline $\mathrm{X} 2$ & Bad Weather Conditions (Rain) & $\begin{array}{l}\text { Shanty and } \\
\text { Fabian, } 2019\end{array}$ \\
\hline X3 & Field conditions that are difficult to reach & $\begin{array}{l}\text { Reyner and } \\
\text { Bonny, } 2015\end{array}$ \\
\hline $\mathrm{X} 4$ & Social problems & $\begin{array}{l}\text { Shanty and } \\
\text { Fabian, } 2019\end{array}$ \\
\hline X5 & There is a problem of land acquisition & $\begin{array}{l}\text { Shanty and } \\
\text { Fabian, } 2019\end{array}$ \\
\hline $\mathrm{X} 6$ & $\begin{array}{l}\text { Social disturbances from the surrounding } \\
\text { community }\end{array}$ & Evan, 2017 \\
\hline $\mathrm{X} 7$ & The level of safety of the project environment & Evan, 2017 \\
\hline $\mathrm{X} 8$ & Disputes occur with the local community & $\begin{array}{l}\text { Iswanto and Hari, } \\
2017\end{array}$ \\
\hline $\mathrm{X} 9$ & Work accident & Evan, 2017 \\
\hline $\mathrm{X} 10$ & Unstable social and political environment & $\begin{array}{l}\text { Iswanto and Hari, } \\
2017\end{array}$ \\
\hline $\mathrm{X} 11$ & $\begin{array}{l}\text { Lack of support from the local government for } \\
\text { project activities }\end{array}$ & $\begin{array}{l}\text { Iswanto and Hari, } \\
2017\end{array}$ \\
\hline $\mathrm{X} 12$ & $\begin{array}{l}\text { Uncertainty from local government policy on } \\
\text { project activities }\end{array}$ & $\begin{array}{l}\text { Iswanto and Hari, } \\
2017\end{array}$ \\
\hline $\mathrm{X} 13$ & $\begin{array}{l}\text { The emergence of congestion around the } \\
\text { project site }\end{array}$ & $\begin{array}{c}\text { Fahmi and } \\
\text { Miftahul, } 2018\end{array}$ \\
\hline $\mathrm{X} 14$ & Job location not ready & $\begin{array}{c}\text { Results of } \\
\text { Interview, } 2019\end{array}$ \\
\hline $\mathrm{X} 15$ & Changes in design and scope of work & $\begin{array}{c}\text { Fahmi and } \\
\text { Miftahul, } 2018\end{array}$ \\
\hline
\end{tabular}


Table 1. Research Variables

\begin{tabular}{|c|c|c|}
\hline Variables & Risks that affect time performance & Sources \\
\hline $\mathrm{X} 16$ & Project scheduling is not perfect & $\begin{array}{l}\text { Shanty and } \\
\text { Fabian, } 2019\end{array}$ \\
\hline $\mathrm{X} 17$ & Redesign occurred & Evan, 2017 \\
\hline X18 & Low productivity & $\begin{array}{l}\text { Shanty and } \\
\text { Fabian, } 2019\end{array}$ \\
\hline $\mathrm{X} 19$ & Added scope of work & Evan, 2017 \\
\hline X20 & Working drawings aren't ready yet & $\begin{array}{c}\text { Results of } \\
\text { Interview, } 2019\end{array}$ \\
\hline $\mathrm{X} 21$ & $\begin{array}{l}\text { The capacity of the project implementers is } \\
\text { lacking }\end{array}$ & $\begin{array}{l}\text { Reyner and } \\
\text { Bonny, } 2015\end{array}$ \\
\hline $\mathrm{X} 22$ & $\begin{array}{l}\text { The level of expertise of the workforce is not } \\
\text { enough }\end{array}$ & $\begin{array}{l}\text { Shanty and } \\
\text { Fabian, } 2019\end{array}$ \\
\hline $\mathrm{X} 23$ & $\begin{array}{l}\text { Personnel competence is not in accordance } \\
\text { with their duties }\end{array}$ & $\begin{array}{l}\text { Shanty and } \\
\text { Fabian, } 2019\end{array}$ \\
\hline $\mathrm{X} 24$ & Lack of teamwork & Evan, 2017 \\
\hline X25 & The division of tasks and authority is not clear & $\begin{array}{l}\text { Shanty and } \\
\text { Fabian, } 2019\end{array}$ \\
\hline $\mathrm{X} 26$ & Less competent core project staff & Evan, 2017 \\
\hline $\mathrm{X} 27$ & Changes to specifications & Evan, 2017 \\
\hline $\mathrm{X} 28$ & Error estimating time & $\begin{array}{l}\text { Shanty and } \\
\text { Fabian, } 2019\end{array}$ \\
\hline X29 & Cost estimation error & $\begin{array}{l}\text { Shanty and } \\
\text { Fabian, } 2019\end{array}$ \\
\hline X30 & $\begin{array}{l}\text { The material used does not meet } \\
\text { specifications }\end{array}$ & $\begin{array}{l}\text { Shanty and } \\
\text { Fabian. } 2019\end{array}$ \\
\hline X31 & Material and equipment delivery errors & Evan, 2017 \\
\hline X32 & Material delivery delays & $\begin{array}{c}\text { Fahmi and } \\
\text { Miftahul, } 2018\end{array}$ \\
\hline X33 & Equipment delivery delays & $\begin{array}{l}\text { Reyner and } \\
\text { Bonny, } 2015\end{array}$ \\
\hline X34 & $\begin{array}{l}\text { Difficulty getting material according to } \\
\text { specifications }\end{array}$ & Evan, 2017 \\
\hline X35 & Increase in material prices & $\begin{array}{l}\text { Reyner and } \\
\text { Bonny, } 2015\end{array}$ \\
\hline X36 & Equipment damage & Evan, 2017 \\
\hline X37 & Lack of equipment & Evan, 2017 \\
\hline X38 & Equipment that is not feasible & $\begin{array}{l}\text { Reyner and } \\
\text { Bonny, } 2015\end{array}$ \\
\hline X39 & Late payment by the project owner & $\begin{array}{l}\text { Iswanto and Hari, } \\
2017\end{array}$ \\
\hline X40 & $\begin{array}{l}\text { The number of results of work that must be } \\
\text { repeated because of wrong (rework) }\end{array}$ & $\begin{array}{l}\text { Iswanto and Hari, } \\
2017\end{array}$ \\
\hline X41 & $\begin{array}{l}\text { Identification, duration, incomplete and non- } \\
\text { sequential work sequence plan }\end{array}$ & $\begin{array}{l}\text { Iswanto and Hari, } \\
2017\end{array}$ \\
\hline $\mathrm{X} 42$ & Accidents happen to workers & $\begin{array}{l}\text { Iswanto and Hari, } \\
2017\end{array}$ \\
\hline $\mathrm{X} 43$ & Difficulties in mobilizing tools and materials & $\begin{array}{l}\text { Iswanto and Hari, } \\
2017\end{array}$ \\
\hline
\end{tabular}

(Source : Processed by the author, 2019) 
The population in this study were all staff and workers involved in the foundation work of the 6th Toll Road Construction Project in the City Section 1A Kelapa Gading - Pulo Gebang consisting of the main contractor, consultant, foundation contractor and field supervisor. From a total population of around 30 people and the percentage of inaccuracy used by $5 \%$ using the Slovin formula obtained the number of samples taken was 28 people. The respondent's identity can be described into several criteria, namely education, work experience in the field of foundation construction and position.

\section{RESULT AND DISCUSSION}

The data that has been collected will be carried out statistical analysis as follows:

a. Results of validity test

The sample data used was $28(\mathrm{~N}=28)$ and the significance level used was $5 \%$, then by looking at the $r$ Product Moment Value table, the $r$ value $=0.374$ was obtained. Then the $r$ count is obtained by using SPSS software and the results can be seen in Table 2 .

Table 2. Results of Validity Test

\begin{tabular}{|c|l|l|l|l|l|}
\hline Code & $\begin{array}{c}\text { Scale } \\
\text { Mean if } \\
\text { Item } \\
\text { Deleted }\end{array}$ & $\begin{array}{c}\text { Scale } \\
\text { Variance } \\
\text { if Item } \\
\text { Deleted }\end{array}$ & $\begin{array}{c}\text { Corrected } \\
\text { Item-Total } \\
\text { Correlation }\end{array}$ & r table & Remark \\
\hline X1 & 79.18 & 391.485 & .837 & 0,374 & Valid \\
\hline X2 & 79.07 & 388.143 & .732 & 0,374 & Valid \\
\hline X3 & 78.93 & 402.661 & .554 & 0,374 & Valid \\
\hline X4 & 79.07 & 404.810 & .679 & 0,374 & Valid \\
\hline X5 & 79.43 & 392.476 & .780 & 0,374 & Valid \\
\hline X6 & 79.11 & 385.729 & .762 & 0,374 & Valid \\
\hline X7 & 79.11 & 384.692 & .866 & 0,374 & Valid \\
\hline X8 & 78.71 & 396.508 & .623 & 0,374 & Valid \\
\hline X9 & 79.57 & 414.106 & .619 & 0,374 & Valid \\
\hline X10 & 79.14 & 414.571 & .420 & 0,374 & Valid \\
\hline X11 & 79.82 & 398.152 & .750 & 0,374 & Valid \\
\hline X12 & 80.18 & 411.485 & .530 & 0,374 & Valid \\
\hline X13 & 79.61 & 416.470 & .537 & 0,374 & Valid \\
\hline X14 & 78.61 & 421.951 & .452 & 0,374 & Valid \\
\hline X15 & 80.07 & 394.143 & .805 & 0,374 & Valid \\
\hline X16 & 79.43 & 423.217 & .048 & 0,374 & Valid \\
\hline X17 & 79.18 & 421.337 & .178 & 0,374 & Not Valid \\
\hline X18 & 78.96 & 407.295 & .495 & 0,374 & Valid \\
\hline X19 & 78.64 & 409.571 & .421 & 0,374 & Valid \\
\hline X20 & 79.00 & 408.889 & .648 & 0,374 & Valid \\
\hline X21 & 79.18 & 377.411 & .891 & 0,374 & Valid \\
\hline X22 & 78.96 & 387.073 & .727 & 0,374 & Valid \\
\hline X23 & 79.14 & 387.608 & .875 & 0,374 & Valid \\
\hline X24 & 79.14 & 386.942 & .891 & 0,374 & Valid \\
\hline X25 & 78.82 & 376.597 & .835 & 0,374 & Valid \\
\hline X26 & 78.54 & 400.851 & .576 & 0,374 & Valid \\
\hline X27 & 78.96 & 405.888 & .714 & 0,374 & Valid \\
\hline X28 & 79.29 & 384.434 & .851 & 0,374 & Valid \\
\hline X29 & 80.04 & 417.369 & .404 & 0,374 & Valid \\
\hline X30 & 79.79 & 418.026 & .185 & 0,374 & Not Valid \\
\hline X31 & 79.86 & 410.868 & .437 & 0,374 & Valid \\
\hline & & & & & \\
\hline
\end{tabular}




\begin{tabular}{|l|l|l|l|l|l|}
\hline X32 & 79.96 & 419.073 & .344 & 0,374 & Not Valid \\
\hline X33 & 80.21 & 419.878 & .212 & 0,374 & Not Valid \\
\hline X34 & 80.21 & 422.471 & .173 & 0,374 & Not Valid \\
\hline X35 & 80.14 & 418.053 & .324 & 0,374 & Not Valid \\
\hline
\end{tabular}

(Source : Result by the author, 2020)

Pada tabel di atas dapat dilihat bahwa variabel X17, X30, X32, X33, X34 dan X35 dianggap tidak valid karena $r$ hitung masih di bawah $r$ tabel. Kemudian keenam variabel tersebut dihilangkan dari proses analisa data selanjutnya.

b. Results of Realibility Test

Results of Realibility Test can be seen in Table 3 :

Tabel 3. Results of Realibility Test

\begin{tabular}{|c|c|}
\hline $\begin{array}{c}\text { Nilai Cronbach's } \\
\text { Alpha }\end{array}$ & N of Items \\
\hline 0,950 & 35 \\
\hline
\end{tabular}

(Source : Result by the author, 2020)

Cronbach's Alpha coefficient value of risk data which have an impact on time performance is obtained 0.950 where the value is greater than 0.5 so that the instrument used in retrieving the data can be said to be reliable.

c. Risk Analysis

After knowing the value of the frequency scale and the impact of events then make a weighting with the average results of the impact value and probability value. Furthermore, the average probability value is multiplied by the average impact value and the highest variables are taken to produce the results as the dominant risk affecting project time performance. To determine the risk level of research variables, the results of the above calculations are matched with the opportunity and impact matrix.

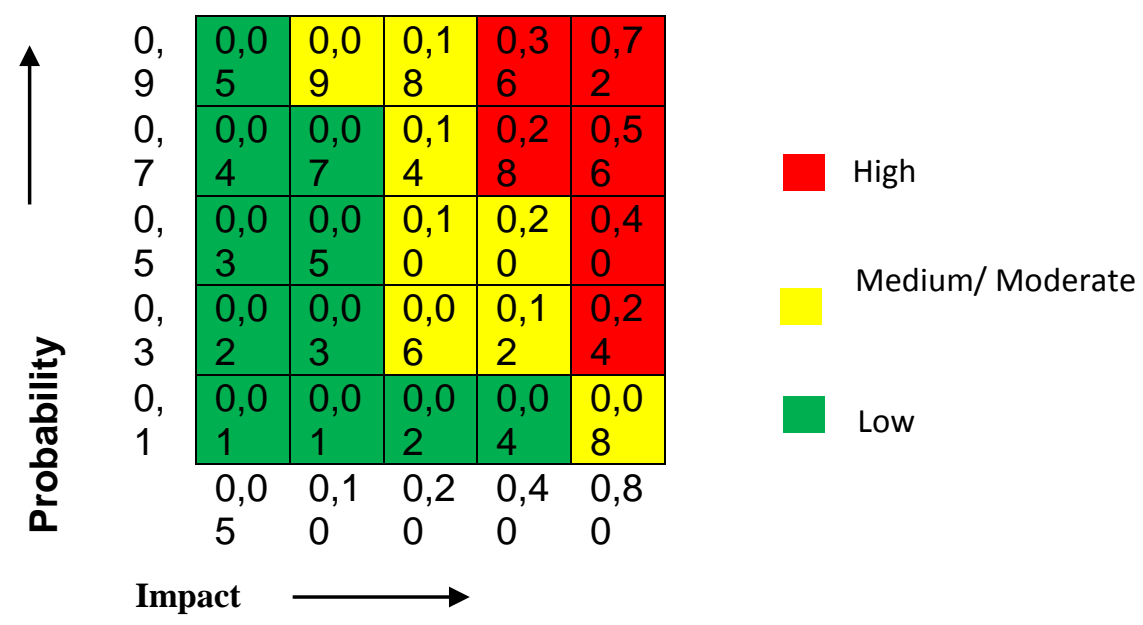

Figure 3. Probability and Impact Matrix (Source : PMBOK, 2017)

Based on Figure 3. the risk rating range can be determined as follows:
1. Low risk $=0.01-0.05$
2. Moderate risk $=0.06-0.19$
3. High risk $=0.20-0.72$ 
Risk calculations and risk rating categories can be seen in the table below:

Table 4. Risk Value and Risk Rating Category

\begin{tabular}{|c|c|c|c|c|}
\hline Code & $\begin{array}{c}\text { Frequency } \\
\text { (I) }\end{array}$ & $\begin{array}{l}\text { Impact } \\
\text { (P) }\end{array}$ & $\begin{array}{c}\text { Risk Value } \\
(\mathrm{I} \times \mathrm{P})\end{array}$ & $\begin{array}{c}\text { Risk Rating } \\
\text { Category }\end{array}$ \\
\hline $\mathrm{X} 1$ & 0.21 & 0.23 & 0.05 & Low \\
\hline $\mathrm{X} 2$ & 0.24 & 0.26 & 0.06 & Low \\
\hline $\mathrm{X3}$ & 0.41 & 0.41 & 0.17 & Moderate \\
\hline $\mathrm{X} 4$ & 0.25 & 0.25 & 0.06 & Moderate \\
\hline$\times 5$ & 0.64 & 0.68 & 0.44 & High \\
\hline $\mathrm{X} 6$ & 0.23 & 0.24 & 0.06 & Moderate \\
\hline X7 & 0.39 & 0.39 & 0.15 & Moderate \\
\hline $\mathrm{X} 8$ & 0.22 & 0.23 & 0.05 & Low \\
\hline $\mathrm{X9}$ & 0.43 & 0.43 & 0.18 & Moderate \\
\hline $\mathrm{X} 10$ & 0.66 & 0.65 & 0.43 & High \\
\hline $\mathrm{X} 11$ & 0.33 & 0.33 & 0.11 & Moderate \\
\hline $\mathrm{X} 12$ & 0.24 & 0.24 & 0.06 & Moderate \\
\hline $\mathrm{X} 13$ & 0.31 & 0.31 & 0.10 & Moderate \\
\hline$\times 14$ & 0.63 & 0.66 & 0.42 & High \\
\hline $\mathrm{X} 15$ & 0.33 & 0.33 & 0.11 & Moderate \\
\hline $\mathrm{X} 16$ & 0.43 & 0.43 & 0.18 & Moderate \\
\hline $\mathrm{X} 17$ & 0.44 & 0.44 & 0.19 & Moderate \\
\hline $\mathrm{X} 18$ & 0.49 & 0.39 & 0.19 & Moderate \\
\hline $\mathrm{X} 19$ & 0.21 & 0.24 & 0.05 & Low \\
\hline $\mathrm{X} 20$ & 0.66 & 0.69 & 0.46 & High \\
\hline $\mathrm{X} 21$ & 0.39 & 0.39 & 0.15 & Moderate \\
\hline $\mathrm{X} 22$ & 0.46 & 0.39 & 0.18 & Moderate \\
\hline$\times 23$ & 0.49 & 0.39 & 0.19 & Moderate \\
\hline $\mathrm{X} 24$ & 0.46 & 0.41 & 0.19 & Moderate \\
\hline$\times 25$ & 0.33 & 0.33 & 0.11 & Moderate \\
\hline $\mathrm{X} 26$ & 0.43 & 0.43 & 0.18 & Moderate \\
\hline $\mathrm{X} 27$ & 0.44 & 0.41 & 0.18 & Moderate \\
\hline $\mathrm{X} 28$ & 0.49 & 0.39 & 0.19 & Moderate \\
\hline $\mathrm{X} 29$ & 0.23 & 0.45 & 0.10 & Moderate \\
\hline X30 & 0.28 & 0.28 & 0.08 & Moderate \\
\hline X31 & 0.26 & 0.26 & 0.07 & Moderate \\
\hline X32 & 0.24 & 0.24 & 0.06 & Moderate \\
\hline X33 & 0.19 & 0.24 & 0.05 & Low \\
\hline X34 & 0.19 & 0.19 & 0.04 & Low \\
\hline X35 & 0.21 & 0.21 & 0.04 & Low \\
\hline
\end{tabular}

(Source : Result by the author, 2020)

From the results of the phase III data analysis, four risk variables are included in the high category and can be seen in Table 5.

Table 5. High Risk that Affect Time Performance

\begin{tabular}{|c|l|}
\hline Code & \multicolumn{1}{c|}{ Risk that Affect Time Performance } \\
\hline X5 & Problem of Land Acquisition \\
\hline X10 & Site Location has not ready for work \\
\hline X14 & The working drawing is not ready \\
\hline X20 & Inadequate core project personnel \\
\hline
\end{tabular}

(Source : Result by the author, 2020) 


\section{CONCLUSION}

Based on the results of research and discussion of the data analysis process, conclusions can be drawn including:

1. Based on the results obtained from the risk analysis it is known that of the 35 variables there are 4 variables that have a high level of risk that affect the time performance of the implementation of foundation work which is stated with a value of $0.20-0.72$ and has been validated by 3 experts as the following:

- There is a problem of land acquisition (X5)

- Site location has not ready for work (X10)

- The working drawing is not ready (X14)

- Inadequate core project personnel (X20)

2. From the results of stage IV data collection, recommendations for preventive actions and corrective actions resulting from the two risk variables are obtained. The recommendations of the three experts are as follows:

a. Land acquisition issues (X5)

- Preventive action: clear scope of work in the contract, be careful in starting the implementation time and pay attention to environmental aspects related to each work item and carefully review the scope of work on the contract.

- Corrective action: filing a claim against the employer, paying attention to environmental aspects at each start of the implementation period for the connection of each work item and submitting an amendment to the contract amendment to the employer.

b. Work location not ready (X10)

- Preventive action: joint survey between employers, contractors and consultants, remeasuring work sites, and reviewing the suitability of work sites with contracts.

- Corrective action: joint meeting to find the best solution for land acquisition, and submission of new contract improvements to employers.

c. Working drawings not ready (X14)

- Preventive action: the design has been approved before the project starts and ensures the forcont drawing before starting the project.

- Corrective action: submit a claim to the employer regarding the unfinished picture by the planner, submit the corrected drawing of the forcont picture to the planner and monitor every change in the detailed picture.

d. Inadequate core project personnel (X20)

- Preventive action: provide training to project staff, set high standards for each new recruitment force and provide incentive / reward money for each competitive core of the project.

- Corrective action: recruit workers according to the needs and competency standards, regeneration of less productive workers and termination of employment contracts to incompetent core workers.

\section{Suggestion}

In carrying out the work in the 6 (Six) Toll Roads Construction Project in the City of Jakarta, 4 high risks were found that affected time performance. For this reason, the author can provide some suggestions that might be useful for the parties concerned:

1. The contractor must take into account the non-productive time caused by the problem of land acquisition, location and work drawings that are not ready in preparing the project implementation plan.

2. Improve the quality of core staff by holding training on project management.

3. Improving the quality of work results by monitoring work and controlling whether the work is in accordance with the plan.

4. The need to apply Project Risk Management Analysis which must be applied to each project so that the risks that occur can be anticipated from the beginning. 


\section{REFERENCES}

[1] A Guide to Management Body of Knowledge (PMBOK Guide) $6^{\text {th }}$ Edition, Project Management Institute (PMII), USA 2017.

[2] Ahmad, Tahir dan Nurul Cahyati. (2018). Analisa Risiko pada Tahap Konstruksi Pembangunan Pembangkit Listrik Tenaga Minihidro (PLTM) Pongkor. Jurnal UMJ Seminar Nasional Sains dan Teknologi 2018 ISSN: 2460 - 8416.

[3] Batubara, Fanny Yuliana, Alizar Hasan dan M. Nursyaifi Yulius. (2014). Identifikasi FaktorFaktor Risiko yang Mempengaruhi Kinerja Waktu Proses Pemasangan Perpipaan Perusahaan Air Minum.

[4] Cakmak, Pinar Irlayici and Ecem Tezel. (2019). A Guide for Risk Management in Construction Projects : Present Knowledge and Future Directions. DOl:http://dx.doi.org/10.5772/intechopen.84361

[5] Data-Data Proyek, PT. IPR.

[6] Iribaram, Wati Fahmi dan Miftahul Huda. (2018). Analisa Resiko Biaya dan Waktu Konstruksi pada Proyek Pembangunan Apartemen Biz Square Rungkut Surabaya. Jurnal Rekayasa dan Manajemen Konstruksi ISSN 2615-0824 Vol. 6, No. 3, Desember 2018, Hal 141-154.

[7] Kalangit, ShantyVon Novita, Fabian J. Manoppo dan Shirley S. Lumeno. (2019). Model Pengelolaan Risiko pada Pembangunan Jalan Lingkar Utara Siau Guna Peningkatan Kinerja Proyek. Jurnal Sipil Statik Vol. 7 No. 1 Januari 2019 (1-14) ISSN: 2337 - 6732.

[8] Karunia, Meutia Nadia. (2016). Analisis Risiko Keterlambatan Waktu Pada Proyek (Studi Kasus : Pembangunan Jalan Tol Trans Sumatera Bakauheni - Terbanggi Besar). Jurnal Teknik Sipil Universitas Lampung.

[9] Nurlela dan Heri (2014. Identifikasi dan Analisis Manajemen Risiko pada Proyek Pembangunan Infrastruktur Bangunan Gedung Bertingkat. Jurnal Desain Konstruksi Volume 13 No. 2, Desember 2014.

[10]Rumimper, Reyner R., Bonny F. Sompie dan Marthin D.J. Sumajouw. (2015). Analisis Resiko pada Proyek Konstruksi Perumahan di Kabupaten Minahasa Utara. Jurnal IImiah Media Engineering Vol. 5 No. 2, September 2015 (381-389) ISSN : 2087-9334.

[11]Sebayang, Enma Mediawati, Hary Agus Rahardjo dan Dwi Dinariana. (2018). Pengelolaan Risiko Proyek Gedung Bertingkat pada PT. XYZ di Jakarta terhadap Kinerja Waktu. Jurnal Teknik Sipil ISSN 0853-2982 Vol. 25 No.3, Desember 2018.

[12] Suarno .(2017). Analisis Kinerja Waktu Pelaksanaan Proyek Konstruksi Studi Kasus Proyek Pembangunan Terminal Multi Purpose dan Fasilitas Pendukung di Kuala Tanjung, Sumatera Utara. Jurnal Fakultas Teknik Universitas Pasir Pengaraian.

[13] Sugiyono. 2016. Statistika Untuk Penelitian. Bandung : Alfabeta.

[14]Undang-Undang Nomor 38 Tahun 2004, Tentang Jalan.

[15]Wijaya, Evan Kusuma, Edhi Wahjuni Setyowati dan Yulvi Zaika. (2017). Analisa Pengendalian Risiko Terhadap Peningkatan Kinerja Pekerjaan Konstruksi. Jurnal online Rekayasa Sipl/ Volume 11, No.2-2017 ISSN 1978 - 5658. 